\title{
Ciri Anatomi, Morfologi Serat, dan Sifat Fisis Tiga Jenis Lesser-Used Wood Species Asal Kalimantan Utara, Indonesia
}

\section{(Anatomical Characteristics, Fiber Morphology, and Physical Properties of Three Lesser Used Wood Species Grown in North Kalimantan, Indonesia)}

\author{
Sarah Augustina', Imam Wahyudi ${ }^{\star}$, I Wayan Darmawan², Jamaludin Malik ${ }^{3}$
}

(Diterima Maret 2020/Disetujui Juli 2020)

\begin{abstract}
ABSTRAK
Tujuan penelitian adalah mengkaji ciri anatomi, morfologi serat, dan beberapa sifat fisis penting dari tiga jenis kayu kelompok lesser-used species asal Kalimantan Utara yakni nyatoh (Palaquium lanceolatum), pisang putih (Mezzettia leptopoda), dan sepetir (Sindora wallichii) guna mendukung pemanfaatan kayu secara tepat guna. Semua parameter dianalisis menggunakan prosedur standar untuk masing-masing sifat. Dari segi anatomi, hasil penelitian menunjukkan pori-pori kayu nyatoh sebagian besar bergabung radial dan berisi tilosis, jari-jarinya satu ukuran, halus dan rapat, sedangkan parenkim aksialnya dalam bentuk garis tangensial pendek dengan jarak yang tidak teratur. Ciri khas kayu pisang putih adalah pori-pori dominan soliter, jari-jari dua ukuran, sedangkan parenkim aksialnya dalam bentuk pita tangensial panjang dalam jarak yang tidak teratur. Untuk kayu sepetir, ciri khasnya adalah pori-pori soliter dalam pola radial dan diagonal, jari-jari dua ukuran tapi kurang jelas, parenkim aksial tipe keliling pembuluh hingga aliform, dan memiliki saluran antarsel dalam deretan tangensial panjang. Rata-rata panjang serat dan tebal dinding serat ketiganya adalah 1904 dan 3,61 $\mu \mathrm{m}$ (nyatoh), 1708 dan 4,51 $\mu \mathrm{m}$ (pisang putih), serta 1337 dan 3,39 $\mu \mathrm{m}$ (sepetir). Rata-rata berat jenis kayu dan T/R-rasionya berturut-turut adalah 0,42 dan 1,41 (nyatoh), 0,37 dan 2,34 (pisang putih), serta 0,32 dan 1,40 (sepetir). Kayu nyatoh masuk ke dalam Kelas Kuat III, sedangkan kayu sepetir dan pisang putih masuk ke dalam Kelas Kuat IV. Dibandingkan dengan pisang putih dan sepetir, kayu nyatoh lebih berpotensi dijadikan bahan baku pembuatan pulp dan kertas serta mebel.
\end{abstract}

Kata kunci: ciri anatomi, lesser-used wood species, morfologi serat, sifat fisis

\section{ABSTRACT}

The purpose of this study was to analyze anatomical characteristics, fiber morphology, and several important physical properties of nyatoh (Palaquium lanceolatum), pisang putih (Mezzettia leptopoda), and sepetir (Sindora wallichit) wood from North Kalimantan in order to support the proper utilization of each wood species. All parameters were analyzed using their standard procedures. Results showed that anatomical characteristics of nyatoh wood are the vessels predominantly are in radial multiples and contained tyloses, ray parenchyma is mostly uniseriate and even, while axial parenchyma is in narrow tangential line with irregularly spaced. For pisang putih wood, the vessels are exclusively solitary, ray parenchyma of two distinct sizes, while axial parenchyma are in continuous tangential bands with irregularly spaced. In case of sepetir wood, the vessel is in radial and diagonal patterns, rays tend to have two different sizes, axial parenchyma is vasicentric to aliform, and has the axial resin canals in continuous tangential bands. Average values of fiber length and fiber wall thickness are 1904 and $3.61 \mu \mathrm{m}$ (nyatoh), 1708 and $4.51 \mu \mathrm{m}$ (pisang putih), and 1337 and $3.39 \mu \mathrm{m}$ (sepetir), respectively; while the mean values of specific gravity and T/R-ratio are 0.42 and 1.41 (nyatoh), 0.37 and 2.34 (pisang putih), and 0.32 and 1.40 (sepetir), respectively. Nyatoh wood is categorized as the Strength Class of III, while pisang putih and sepetir woods are categorized as the Strength Class of IV. Compared to pisang putih and sepetir woods, nyatoh wood is more potential for pulp, paper, and furniture manufacturing.

Keywords: anatomical characteristics, fiber morphology, lesser-used wood species, physical properties

\section{PENDAHULUAN}

Lesser-used wood species (LUS) tergolong sebagai kayu sekunder dan bukan merupakan bahan baku

1 Sekolah Pascasarjana, Fakultas Kehutanan, Institut Pertanian Bogor, Kampus IPB Darmaga, Bogor 16680

2 Departemen Hasil Hutan, Fakultas Kehutanan, Institut Pertanian Bogor, Kampus IPB Darmaga, Bogor 16680

${ }^{3}$ Pusat Penelitian dan Pengembangan Hasil Hutan, Gunung Batu St No.5, Gunungbatu, Bogor 16118

*Penulis Korespondensi: Email: imyudarw16@yahoo.com utama bagi sebagian besar industri perkayuan tanah air. Pohon-pohon kelompok LUS di Indonesia pada umumnya tidak ditebang atau bahkan ditinggalkan setelah penebangan meskipun batangnya lurus, berdiameter besar, dan/atau memiliki tinggi bebas cabang yang memadai (FAO 1984). Hal ini berkaitan dengan informasi yang kurang tentang sifat dan karakteristik kayu-kayu tersebut. Padahal, beberapa kayu LUS diketahui memiliki sifat dan karakteristik yang sama bahkan lebih baik dari yang terdapat pada kayu-kayu komersial. Sebagai contoh adalah kayu samama atau 
jabon merah (Anthocephallus macrophyllus) yang dapat digunakan sebagai pengganti kayu meranti merah (Shorea spp.) karena kemiripan karakteristik di antara keduanya (Cahyono et al. 2016).

Sifat dasar kayu terdiri atas struktur anatomi, sifat fisis, mekanis, kimia, dan keawetan alami (Wahyudi 2013). Struktur anatomi terkait dengan segala hal tentang sel-sel penyusun kayu, sifat fisis terkait dengan keragaan (performance) kayu dalam hubungannya dengan kelembapan udara sekitar $(\mathrm{RH})$, sedangkan sifat mekanis mengindikasikan kekuatan kayu. Komponen kimiawi dinding sel (selulosa, hemiselulosa, lignin, dan zat ekstraktif) akan tergambar dengan jelas dalam sifat kimia kayu, sedangkan ketahanan kayu terhadap semua bentuk faktor perusak akan diuraikan dalam keawetan alami kayu. Sifat-sifat tersebut sangat menentukan proses pengolahan dan tujuan akhir penggunaan kayu. Secara keseluruhan, sifat dasar tersebut akan mencerminkan mutu kayu itu sendiri.

Dari kelima sifat dasar tersebut, informasi struktur anatomi dan sifat fisis terutama kerapatan dan berat jenis (BJ) kayu perlu didahulukan. Selain untuk keperluan identifikasi jenis, struktur anatomi akan memengaruhi mutu proses pengeringan, pengawetan, peningkatan mutu, dan permesinan karena karakteristik kayu melekat pada sel-sel penyusunnya, sedangkan kerapatan dan BJ kayu merupakan indikator penting untuk menduga kekuatan dan sifat mekanis lainnya (Winandy 1994). Menurut Peng et al. (2016) dan Green et al. (2006), terdapat korelasi positif yang kuat antara kerapatan dan/atau BJ kayu dengan kekerasan, sedangkan menurut Mardikanto et al. (2011) dan Augustina (2019), kerapatan dan/atau BJ kayu akan menentukan kekuatannya. Kayu-kayu berkerapatan dan/atau ber-BJ tinggi akan menghasilkan kekuatan patah dan beberapa sifat mekanis lain yang tinggi pula. Menurut Ashori dan Nourbakhsh (2009), Damayanti \& Rulliaty (2010), dan Wahyudi (2013), morfologi serat merupakan indikator penting untuk menilai kesesuaian kayu dan/atau bahan berlignoselulosa lain sebagai bahan baku pembuatan pulp dan kertas bermutu tinggi. Selain itu, morfologi serat erat kaitannya dengan kekuatan dan kekerasan kayu. Menurut Chowdhury et al. (2012), kekerasan dan kekuatan tekan sejajar serat berkorelasi positif dengan tebal dinding sel. Augustina (2019) menambahkan panjang serat berkorelasi positif dengan keteguhan lentur dan kekuatan patah kayu.

Dari sekitar 4000 jenis pohon penghasil kayu potensial yang tumbuh di hutan alam Indonesia, nyatoh (Palaquium spp.), sepetir (Sindora spp.), dan pisang putih (Mezzettia spp.) tergolong kelompok LUS yang kayunya dinilai kurang ekonomis meski sebagian informasi tentang ketiga jenis kayu tersebut sudah dipublikasikan (FAO 1984). Beberapa sifat, karakteristik, dan kegunaan kayu nyatoh (Palaquium spp.) secara umum sudah diteliti (Martawijaya et al. 2005; Ogata et al. 2008). Begitu pula penggunaan kayu nyatoh, khususnya $P$. obtusifolium Burck. sebagai bahan bilah pensil telah diteliti (Mandang \& Suhaendra 2003). Beberapa peneliti lain telah meneliti pertumbuhan anakan nyatoh hasil cabutan alam (Porombi et al. 2017), serta ekologi dan potensi pertumbuhan jenis pohon tersebut di area hutan sekunder (Florensius et al. 2018) dan area pertambangan (Wasis \& Baskara 2013). Menurut Ogata et al. (2008), nyatoh bukan nama untuk satu jenis, namun untuk kelompok jenis, dan baru sebagian kecil saja yang sudah diketahui sifat dan karakteristik kayunya.

Informasi umum terkait kayu pisang putih (Mezzettia spp.) dapat ditemukan dalam buku Prosea 5(3) (Sosef et al. 1998). Sama seperti nyatoh, pisang putih adalah nama untuk kelompok jenis dan baru sebagian kecil di antaranya yang sudah diteliti. Kekayaan jenis dari famili Annonaceae termasuk jenis Mezzettia spp. sudah diteliti oleh Din et al. (2015), sedangkan Handayani (2018) mempelajari diversitas, potensi, dan aspek konservasi famili Annonaceae di Kebun Raya Bogor. Makrofotografi atlas kayu famili Annonaceae dikaji oleh Koek \& Westra (2012).

Sebagian informasi tentang kayu sepetir (Sindora spp.) dapat ditemukan dalam Wood Handbook (FPL 2010) dan laporan ITTO (FPRDI-ITTO 2019). Pe-

manfaatan jenis flora potensial penghasil eksudat termasuk Sindora spp. telah diteliti oleh Boer \& Ella (2000), sedangkan sifat akustiknya oleh Hamdan et al. (2016). Akan tetapi, data yang kurang lengkap tentang sifat dan karakteristik kayu, terutama pada ketiga jenis yang diteliti diyakini menjadi penyebab utama kurang populernya kayu-kayu tersebut sebagai bahan baku industri. Dengan demikian, kajian tentang sifat dan karakteristik ketiga jenis kayu tersebut perlu terus dilakukan dan disosialisasikan.

Berdasarkan uraian di atas maka tujuan penelitian ini adalah mengkaji karakteristik anatomi, morfologi serat, dan beberapa sifat fisis penting dari ketiga jenis kayu LUS, terutama nyatoh (Palaquium lanceolatum), pisang putih (Mezzettia leptopoda), dan sepetir (Sindora wallichii) asal Kalimantan Utara dalam rangka menetapkan tujuan penggunaannya. Ketersediaan data dan informasi yang lebih lengkap akan mendukung pemanfaatan ketiga jenis kayu tersebut secara lebih maksimal. Selain mengatasi masalah kelangkaan bahan baku industri perkayuan di tanah air melalui diversifikasi jenis, hasil penelitian ini juga berkontribusi dalam melestarikan sumber daya hutan yang masih tersisa.

\section{METODE PENELITIAN}

\section{Bahan dan Alat}

Bahan utama yang digunakan adalah disk kayu nyatoh, sepetir, dan pisang putih setebal $30 \mathrm{~cm}$ dan berdiameter $\pm 65 \mathrm{~cm}$ yang berasal dari bagian pangkal batang setinggi dada atau pada ketinggian $130 \mathrm{~cm}$ dpl. Masing-masing jenis diwakili oleh tiga pohon yang berbeda. Semua pohon contoh diperoleh dari kawasan hutan alam sebuah HPH di Provinsi Kalimantan Utara. Disk dikonversi menjadi sampel uji per segmen dengan ukuran $2 \times 2 \times 6 \mathrm{~cm}$. Sampel tersebut 
kemudian dipotong dua (atas dan bawah) untuk menghilangkan keragaman sifat yang ada. Sampel di bagian atas digunakan untuk pengujian struktur anatomi dan morfologi serat, sedangkan yang di bagian bawah untuk pengujian sifat fisis yang meliputi kadar air (KA), kerapatan, dan berat jenis (BJ) ketiganya dalam kondisi kering udara, serta susut dimensi dan perbandingan antara susut tangensial dan radial (T/Rrasio) dari basah ke kondisi kering udara (Gambar 1). Sampel yang digunakan dalam pengujian adalah sampel uji yang bebas dari mata kayu dan terbebas dari cacat-cacat visible lainnya.

\section{Pembuatan Sayatan Mikrotom untuk Pengamatan Ciri Anatomi}

Sampel uji yang digunakan adalah sampel uji yang mewakili bagian teras. Dari masing-masing disk dipilih tiga buah sampel. Sampel direbus dalam air 2-3 hari hingga lunak, kemudian disayat menggunakan mikrotom dengan target ketebalan 20-30 $\mu \mathrm{m}$ yang mewakili bidang lintang $(X)$, radial $(R)$, dan tangensial (T). Sayatan terpilih kemudian direndam dalam safranin $2 \%$ selama 6 jam, lalu dicuci dengan akuades hingga bersih, dan didehidrasi bertingkat menggunakan etanol 30, 50, 70, 90, dan 96\% (absolut) masing-masing 5-10 menit. Sayatan selanjutnya diletakkan di atas gelas objek, ditetesi xylol, direkat dengan entellan (Damayanti et al. 2007), ditutup dengan gelas penutup, dan siap untuk diamati $\mathrm{d}$ bawah mikroskop dan didokumentasi. Ciri anatomi yang diamati sesuai dengan International Association of Wood Anatomist (IAWA 2008).

\section{Pembuatan Preparat Maserasi untuk Pengukuran Morfologi Serat}

Proses maserasi dilakukan mengikuti metode Franklin yang dimodifikasi (Rulliaty 1994). Sampel uji yang digunakan juga yang mewakili bagian teras dengan tiga ulangan. Serat-serat yang diperoleh dari proses maserasi diwarnai dengan safranin $2 \%$ selama 6-8 jam, lalu didehidrasi bertingkat dengan etanol (50, 70,90 , dan $96 \%$ ) masing-masing selama 5 menit.
Serat kemudian dipindahkan ke atas object glass dan langsung diamati di bawah mikroskop cahaya. Panjang, diameter, dan diameter lumen serat adalah rata-rata dari 50 pengukuran sel individu utuh dari setiap contoh uji, sedangkan tebal dinding serat ditetapkan sebagai setengah dari selisih diameter serat dan diameter lumennya. Hasil pengukuran dimensi serat digunakan untuk menghitung nilai turunan dimensi serat yang meliputi Runkle ratio (RR), felting power (FP), Muhlstep ratio (MR), flexibility ratio (FR), dan coefficient of rigidity (CR) menggunakan rumus:

$$
\mathrm{RR}=\frac{2 w}{l} ; \mathrm{FP}={ }^{P} ; \mathrm{MR}=\frac{d^{2}-l^{2}}{d^{2}} ; \mathrm{FR}=\frac{l}{d} ; \mathrm{CR}=\frac{w}{d}
$$

\section{Keterangan:}

$\mathrm{P}=$ Panjang serat

$\mathrm{d}=$ Diameter serat

I = Diameter lumen

$\mathbf{w}=$ Tebal dinding serat

\section{Pengujian Sifat Fisis}

Pengujian dilakukan mengikuti BS 373-1957 (BSI 1957) dengan sedikit modifikasi. Ukuran sampel uji KA, kerapatan, dan BJ kayu adalah $2 \times 2 \times 3 \mathrm{~cm}$, sedangkan untuk susut masing-masing dimensi (longitudinal, radial, dan tangensial) dan T/R-rasio adalah $0,9 \times 2 \times 3 \mathrm{~cm}$. Semua parameter diukur dengan enam ulangan (6 sampel) per jenis kayu. Nilai T/Rrasio dari basah ke kondisi kering udara dijadikan indikator penentu kestabilan dimensi kayu. Menurut Bowyer et al. (2003), kayu dikatakan stabil atau memiliki stabilitas dimensi yang baik apabila T/Rrasionya mendekati 1,00 , dan dikatakan tidak stabil apabila T/R-rasionya $>2,00$. Kayu dengan $\mathrm{T} / \mathrm{R}$-rasio $=$ 2,00 dianggap normal.

\section{Analisis Data}

Data kualitatif disajikan dalam bentuk foto dan dideskripsikan, sedangkan data kuantitatif dihitung nilai rata-rata dan standar deviasinya menggunakan Microsoft Excel. Perbedaan nilai rata-rata untuk setiap jenis ditentukan menggunakan $t$-student pada selang

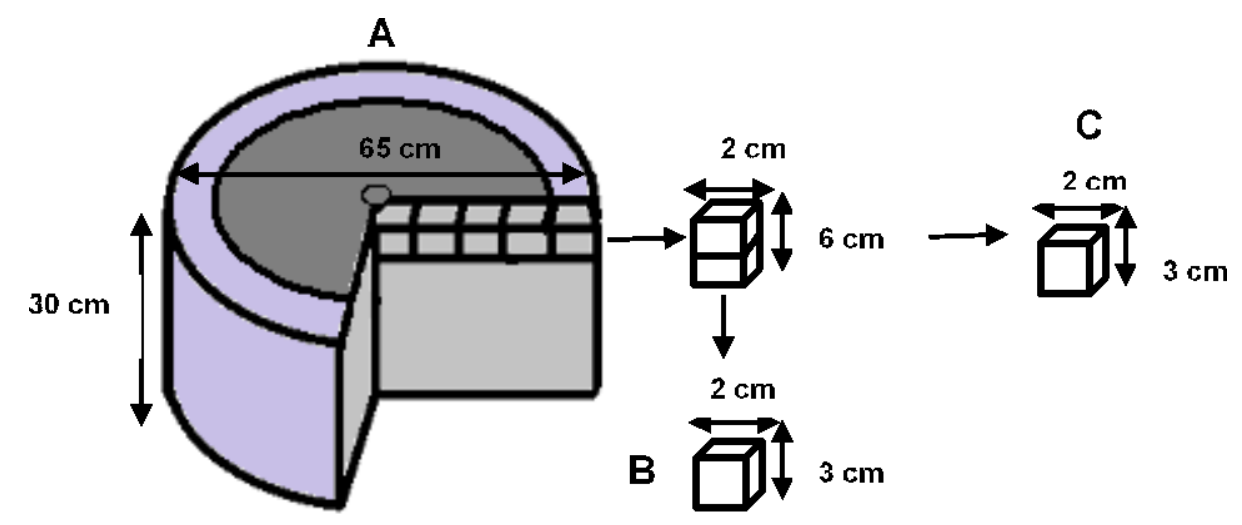

Gambar 1 Pola pembagian dan pembuatan sampel uji. A) Disk setebal $30 \mathrm{~cm}$ dan diameter $65 \mathrm{~cm}$, B) Sampel uji untuk analisis ciri anatomi dan morfologi serat, dan C) Sampel uji untuk pengukuran sifat fisis. 
kepercayaan $95 \%$. Semua analisis statistik diproses dengan perangkat lunak IBM SPSS Statistics 22.

\section{HASIL DAN PEMBAHASAN}

\section{Ciri Anatomi Kayu Nyatoh (Palaquium lanceolatum)}

Hasil penelitian menunjukkan kayu nyatoh memiliki karakteristik sebagai berikut: berwarna cokelat gelap, bertekstur halus, berserat lurus, tidak berbau khas, permukaan kayu agak mengkilap, dan tergolong keras. Lingkar tumbuhnya tidak jelas (Gambar 2A dan 2B). Sel pembuluh (pori-pori) tata baur, sebagian besar bergabung radial 2-4 sel atau lebih (Gambar 2B), ratarata diameter 89,37 $\mu \mathrm{m}$, bidang perforasi sederhana (Gambar 2D), berisi tilosis (Gambar 2A dan 2B), pernoktahan di dinding bersama berhadap-hadapan dan berselang-seling (Gambar 3A), berukuran kecil (4-7 $\mu \mathrm{m})$, dan tidak berumbai; sedangkan pernoktahan di bidang silang berhalaman jelas (Gambar 3B) serupa dalam ukuran dan bentuk dengan noktah yang ada di dinding bersama. Parenkim aksialnya tipe apotrakeal dalam deretan tangensial pendek dengan jarak yang tidak teratur (Gambar 2B). Jari-jarinya 1-2 seri (Gambar 3A), satu ukuran, heteroseluler yang didominasi oleh sel tegak (Gambar $2 \mathrm{C}$ ), tinggi rata-rata 322,36 $\mu \mathrm{m}$, serta berisi endapan dan kristal (Gambar 2C dan 3B). Seratnya bersekat, panjang rata-rata $1903,69 \mu \mathrm{m}$, diameter rata-rata $32,22 \mu \mathrm{m}$, diameter lumen $25,01 \mu \mathrm{m}$, dan tebal dinding $3,61 \mu \mathrm{m}$. Tidak ditemukan adanya saluran interseluler maupun inklusi mineral.

Hasil yang diperoleh hampir serupa dengan laporan Martawijaya et al. (2005) yang menyatakan bahwa warna kayu nyatoh (Palaquium spp.) bervariasi cokelat-kuning hingga cokelat atau merah tua, tekstur agak halus sampai kasar serta mengkilap, arah serat lurus sampai agak berpadu, struktur pori bergabung 2-8 dalam arah radial, hanya sebagian soliter dengan diameter 50-200 $\mu \mathrm{m}$, parenkim tipe apotrakeal bentuk pita halus yang panjang dan teratur, jari-jari termasuk halus dengan lebar $<50 \mu \mathrm{m}$, serta dimensi serat dengan panjang berkisar 1358-2271 $\mu \mathrm{m}$, dan diameter serat berkisar 17,3-30 $\mu \mathrm{m}$.

\section{Ciri Anatomi Kayu Pisang Putih (Mezzettia leptopoda)}

Hasil penelitian menunjukkan kayu pisang putih memiliki karakteristik sebagai berikut: berwarna putih kekuningan, bertekstur kasar, berserat lurus, permukaan agak buram, tidak memiliki bau dan rasa yang khas, dan tergolong lunak. Lingkar tumbuhnya tidak jelas (Gambar 4A dan 4B). Pori-pori tata baur, sebagian besar soliter meski ada juga yang bergabung 2 sel (Gambar 4B), tidak bertilosis, rata-rata diameter 103,33 $\mu \mathrm{m}$, bidang perforasinya sederhana (Gambar $5 \mathrm{~A})$, noktah di dinding bersama berselang-seling (Gambar 5A), berukuran kecil (4-7 $\mu \mathrm{m}$ ) dan tidak berumbai, sedangkan noktah di bidang silang jari-jari
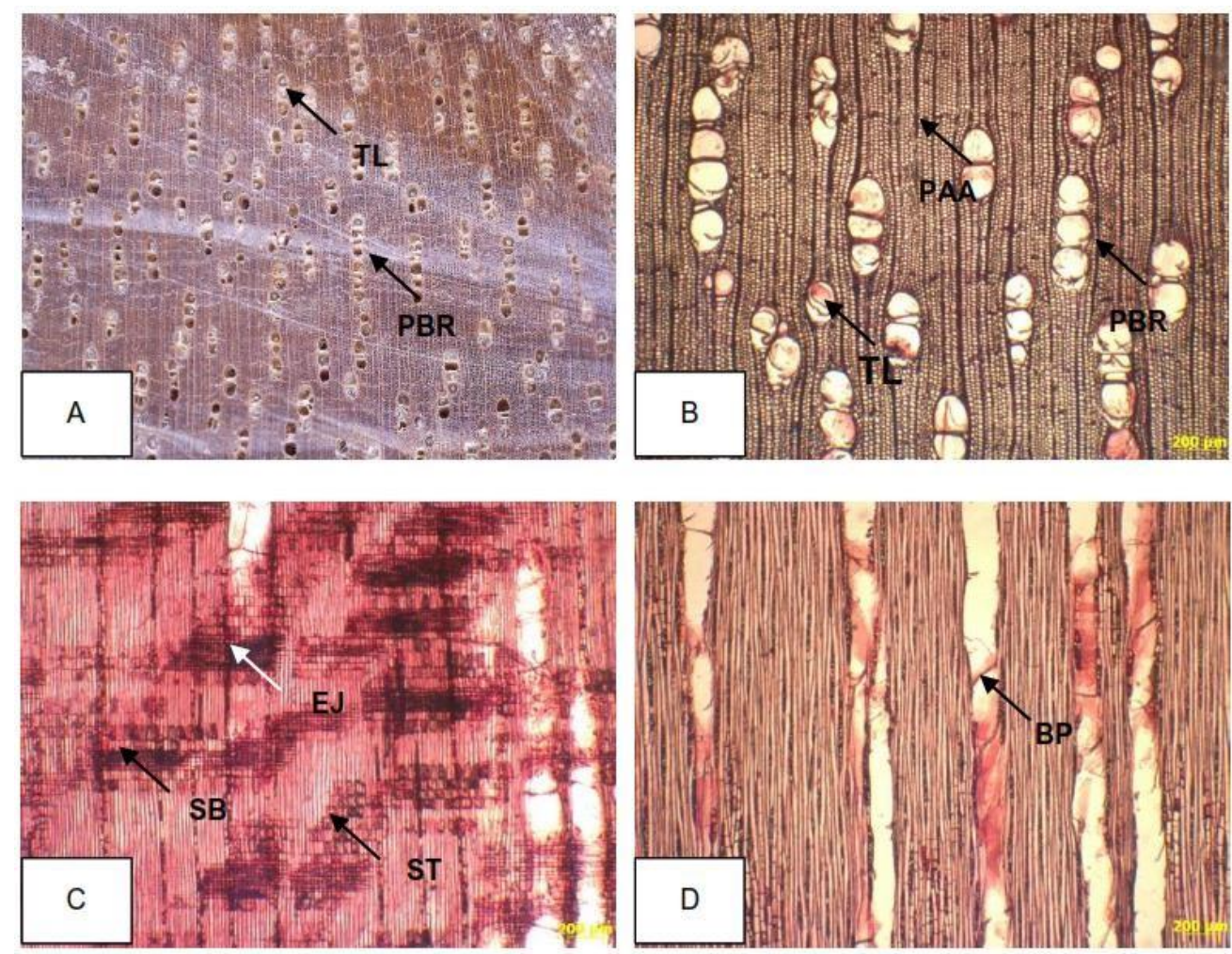

Gambar 2 Hasil pengamatan makro- dan mikroskopis kayu nyatoh: (A) Bidang lintang (10x), (B) Bidang lintang (25x), (C) Bidang radial (25x), dan (D) Bidang tangensial (25x). TL = Tilosis, PAA = Parenkim apotrakeal garis tangensial pendek, PBR = Pori bergabung radial, ST = Sel tegak, SB = Sel baring, EJ = Endapan di dalam jari-jari, dan BP = Bidang perforasi. 

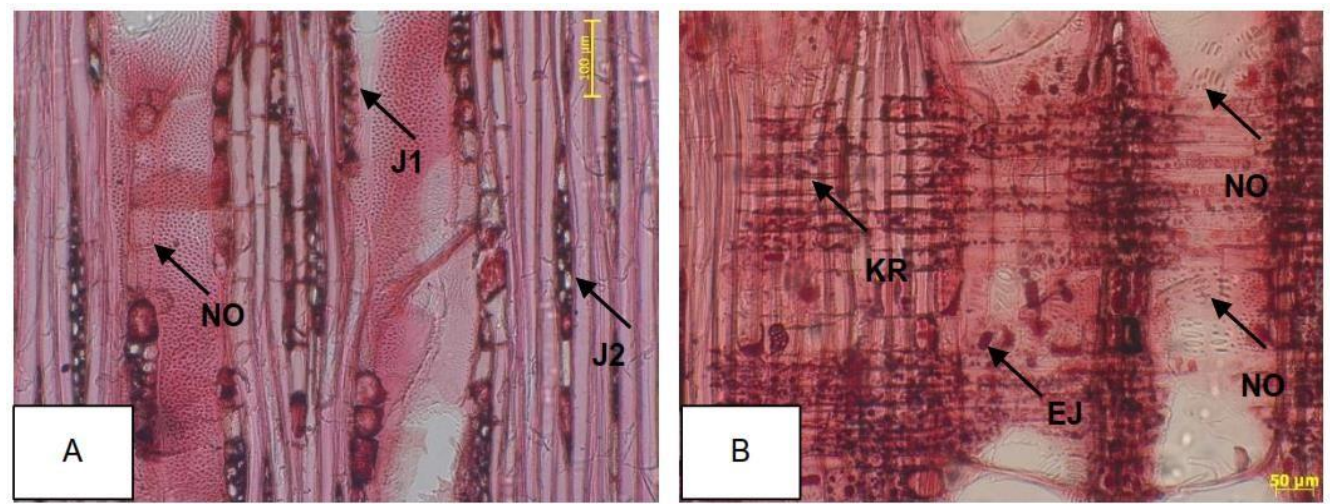

Gambar 3 Jari-jari 1-2 seri ( $\mathrm{J} 1$ dan J2) serta noktah (NO) berhadap-hadapan dan berselang-seling di dinding bersama (A, 100x); noktah (NO) berhalaman jelas di bidang silang jari-jari, serta endapan (EJ) dan kristal (KR) di dalam jarijari kayu $(\mathrm{B}, 100 \mathrm{x})$.
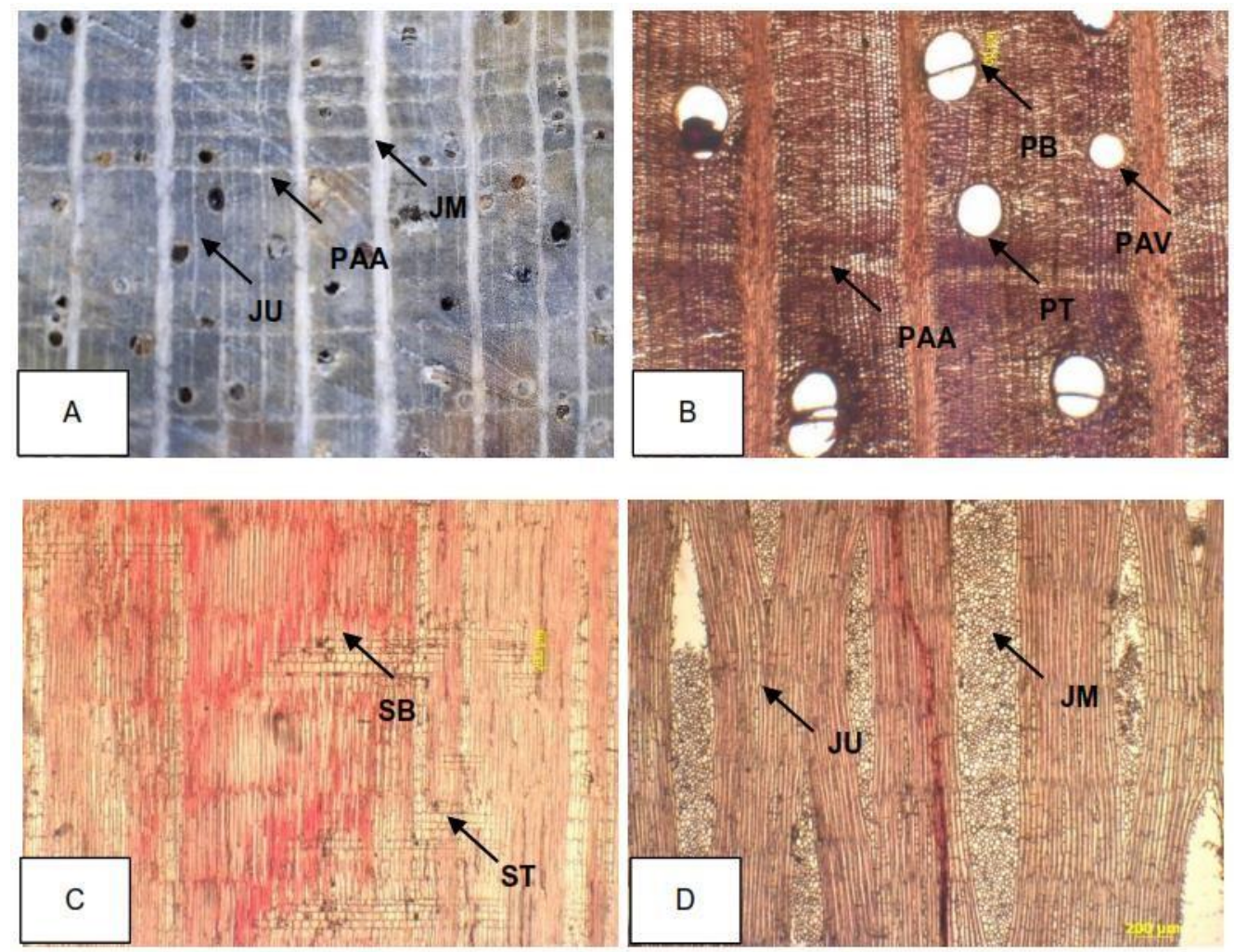

Gambar 4 Hasil pengamatan makro- dan mikroskopis kayu pisang putih: (A) Bidang lintang (10x), (B) Bidang lintang (25x), (C) Bidang radial (25x), dan (D) Bidang tangensial (25x). PAA = Parenkim apotrakeal pita tangensial panjang, PT $=$ Pori soliter, $\mathrm{PB}=$ Pori bergabung 2 sel, $\mathrm{PAV}=$ Parenkim aksial tipe keliling pembuluh (vasisentrik), $\mathrm{ST}=\mathrm{Sel}$ tegak, SB = Sel baring, JM = Jari-jari multiseri, dan JU = Jari-jari uniseri.

berhalaman jelas (Gambar 5B), serupa dalam ukuran dan bentuk dengan noktah di dinding bersamanya. Parenkim aksialnya apotrakeal pita tangensial panjang hingga paratrakeal selubung tipis (Gambar 4A dan 4B). Jari-jarinya kebanyakan multiseriate, dua ukuran jelas (Gambar 4D), dan tersusun oleh sel baring dan sel tegak (Gambar 4C). Seratnya bersekat, panjang ratarata $1708,39 \mu \mathrm{m}$, diameter rata-rata $32,60 \mu \mathrm{m}$, diameter lumen 21,58 $\mu \mathrm{m}$, dan tebal dinding 4,51 $\mu \mathrm{m}$. Kayu tidak memiliki saluran interseluler maupun inklusi mineral.
Hasil yang diperoleh hampir sama dengan laporan ITTO-Tropical Timber-Lesser Used Species (ITTO 2019); Koek \& Westra (2012) menyatakan kayu yang tergolong famili Annonaceae termasuk Mezzettia spp. memiliki ciri: pori-pori dalam pola tata baur dengan diameter pori > $200 \mu \mathrm{m}$, jumlah pori $5-20 / \mathrm{mm}^{2}$, noktah pada cross-fieldnya maupun di dinding bersama (intervessel pitting) memiliki ukuran dan bentuk yang sama, parenkim paratrakeal aksialnya scanty dan/atau keliling pembuluh (vasisentrik) hingga aliform, serta dalam bentuk pita tangensial pendek, jari-jarinya $>4$ 

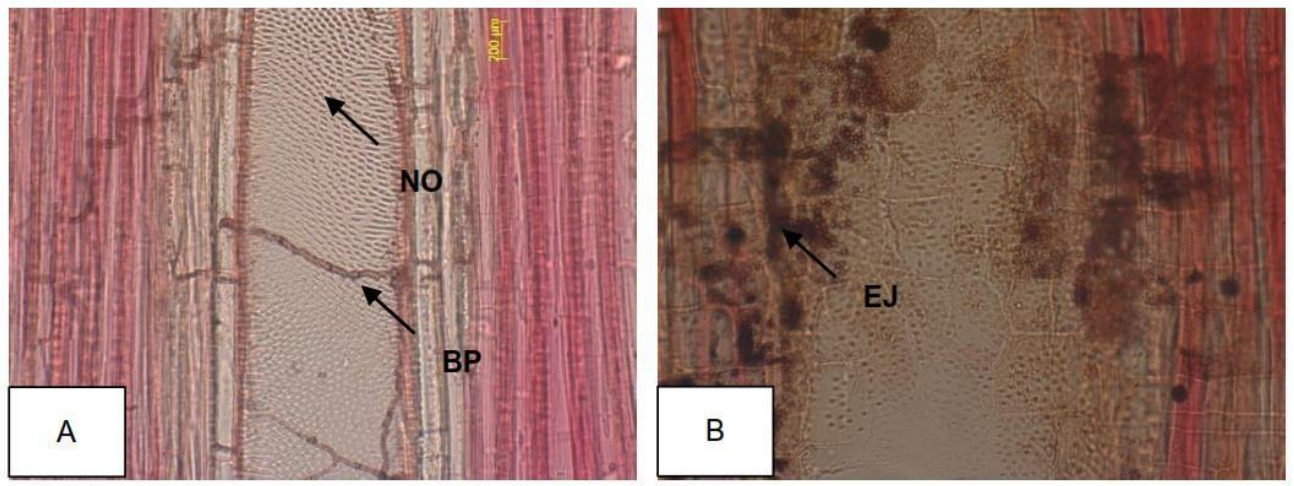

Gambar 5 Bidang perforasi (BP) sederhana dan noktah (NO) selang-seling di dinding bersama (A, 100x); dan endapan (EJ) di dalam parenkim $(B, 150 x)$.

seri, dan memiliki endapan di dalam parenkim aksial maupun di dalam jari-jari.

\section{Ciri Anatomi Kayu Sepetir (Sindora walichii)}

Hasil penelitian menunjukkan kayu sepetir memiliki karakteristik anatomi sebagai berikut: berwarna cokelat gelap, bertekstur halus, berserat lurus, permukaan kayu agak mengkilap, tidak memiliki bau yang khas, dan tergolong keras. Lingkar tumbuhnya kurang jelas. Pori-pori tata baur, sebagian besar soliter dalam pola radial hingga diagonal (Gambar $6 \mathrm{~A}$ ) meski ada juga yang bergabung radial 3 sel (Gambar $6 \mathrm{~A}$ ), rata-rata diameter 101,49 $\mu \mathrm{m}$, bidang perforasi sederhana (Gambar 6D), berisi tilosis (Gambar 6A), noktah di dinding bersama selang-seling (Gambar 7A), berukuran kecil (4-7 $\mu \mathrm{m})$, dan tidak berumbai, sedangkan pernoktahan di bidang silang jari-jari berhalaman jelas (Gambar 7B), serupa dalam ukuran dan bentuk dengan noktah di dinding bersamanya. Parenkim aksialnya tipe keliling pembuluh hingga aliform (Gambar 6B). Jarijarinya 1-2 seri, satu ukuran, hanya memiliki sel baring (Gambar 6C), dengan tinggi rata-rata 321,36 $\mu \mathrm{m}$. Seratnya bersekat, panjang rata-rata 1337,25 $\mu \mathrm{m}$, diameter rata-rata 18,23 $\mu \mathrm{m}$, diameter lumen 11,46 $\mu \mathrm{m}$, dan tebal dinding 3,39 $\mu \mathrm{m}$. Kayu memiliki saluran interseluler dalam bentuk deretan tangensial panjang (Gambar 6A dan 6B), tetapi tidak memiliki inklusi mineral.

Hasil yang diperoleh hampir sama dengan laporan ITTO-Tropical Timber -Lesser Used Species (ITTO 2019) dan FPL (2010) yang menyatakan kayu sepetir (Sindora spp.) memiliki pola susunan pori tata baur dengan bidang perforasi sederhana, noktah antara pori dan jari-jari serta di dinding bersamanya memiliki ukuran dan bentuk yang sama, parenkim apotrakeal aksial kelompok baur dan/atau kelompok baur bergabung, parenkim paratrakeal aksial scanty dan/atau tipe keliling pembuluh hingga aliform.

\section{Morfologi Serat Ketiga Jenis Kayu dan Penentuan Kelas Mutunya}

Rekapitulasi rata-rata panjang serat, nilai turunan dimensi serat, dan kelas mutu serat pada ketiga jenis kayu disajikan pada Tabel 1. Hasil pengukuran memperlihatkan kayu nyatoh memiliki serat yang paling panjang $(1903,69 \mu \mathrm{m})$, sedangkan kayu sepetir paling pendek $(1337,25 \mu \mathrm{m})$. Rata-rata panjang serat kayu pisang putih adalah 1708,39 $\mu \mathrm{m}$. Serat ketiga jenis kayu yang diteliti lebih panjang dibanding panjang serat kayu Acacia spp. yang saat ini paling banyak digunakan sebagai bahan baku pulp dan kertas bermutu tinggi. Menurut Yahya et al. (2010), rata-rata panjang serat kayu akasia adalah $1268 \mu \mathrm{m}$. Dalam kaitannya sebagai bahan baku industri pulp dan kertas, serat yang lebih panjang lebih disukai karena akan menghasilkan pulp dan kertas bermutu tinggi. Semakin panjang serat kayunya maka semakin tinggi pula kekuatan tarik, kekuatan robek, ketahanan lipat, dan burst strength lembaran pulp dan kertas yang dihasilkan.

Hasil pengukuran memperlihatkan rata-rata $R R$ serat kayu nyatoh paling kecil $(0,30)$ lebih kecil dari rata-rata RR serat kayu Acacia hybrid, A. Mangium, dan Eucalyptus spp., yakni 0,36-0,48 (Ona et al. 2001; Yahya et al. 2010), sedangkan pada kayu sepetir paling besar $(0,62)$. Rata-rata RR serat kayu pisang putih adalah 0,54. Semakin rendah $R R$, maka akan semakin tinggi pula mutu pulp dan kertas yang dihasilkan karena serat lebih mudah dipipihkan, lebih mudah dibentuk, dan lebih besar besar pula surface area yang terbentuk. Menurut Istikowati et al. (2016); Ashori \& Nourbakhsh (2009), semakin besar surface area maka semakin kuat pula pulp dan kertas yang dihasilkan karena semakin tinggi ikatan antarseratnya. Nilai FP pada ketiga jenis kayu juga beragam, meski di antara kayu pisang putih dan kayu nyatoh nilai FP keduanya tidak begitu jauh berbeda, masing-masing 53,65 dan 55,85\%, sedangkan FP serat kayu sepetir paling tinggi $(75,00 \%)$. Rata-rata FP pada ketiga jenis kayu yang diteliti lebih tinggi dibandingkan FP serat kayu A. mangium. Menurut Yahya et al. (2010), ratarata FP serat kayu $A$. mangium adalah 51,29\%. Dengan FP yang lebih tinggi maka dapat dipastikan lembaran pulp dan kertas yang akan dihasilkan akan lebih kuat.

Dari segi MR, hasil pengukuran menunjukkan serat kayu nyatoh memiliki nilai yang terendah (40,13\%), sedangkan serat kayu sepetir tertinggi $(60,69 \%)$. Ratarata nilai MR serat kayu pisang putih sebesar 55,99\%. Menurut Ona et al. (2001), semakin rendah MR akan 

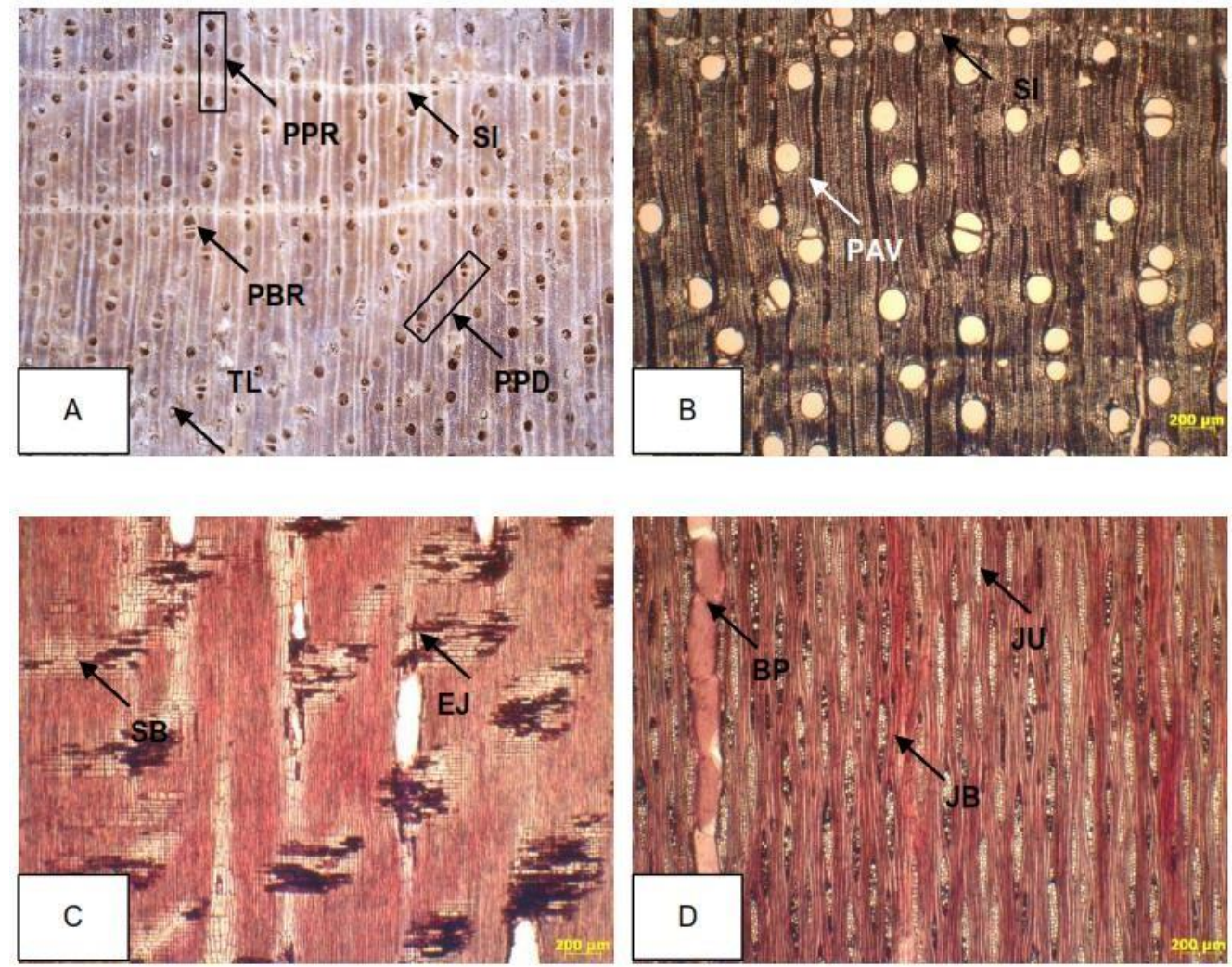

Gambar 6 Hasil pengamatan makro- dan mikroskopis kayu sepetir: (A) Bidang lintang (10x), (B) Bidang lintang (25x), (C) Bidang radial (25x), dan (D) Bidang tangensial (25x). SI = Saluran interseluler, PPR = Pori dalam susunan radial, $\mathrm{PPD}=$ Pori diagonal, $\mathrm{PBR}=$ Pori bergabung, $\mathrm{PAV}=$ Parenkim aksial tipe aliform, EJ = Endapan di dalam jari-jari, $\mathrm{SB}=$ Sel baring, $\mathrm{BP}=$ Bidang perforasi, $\mathrm{JU}=$ Jari-jari uniseri, dan $\mathrm{JB}=$ Jari-jari biseri.
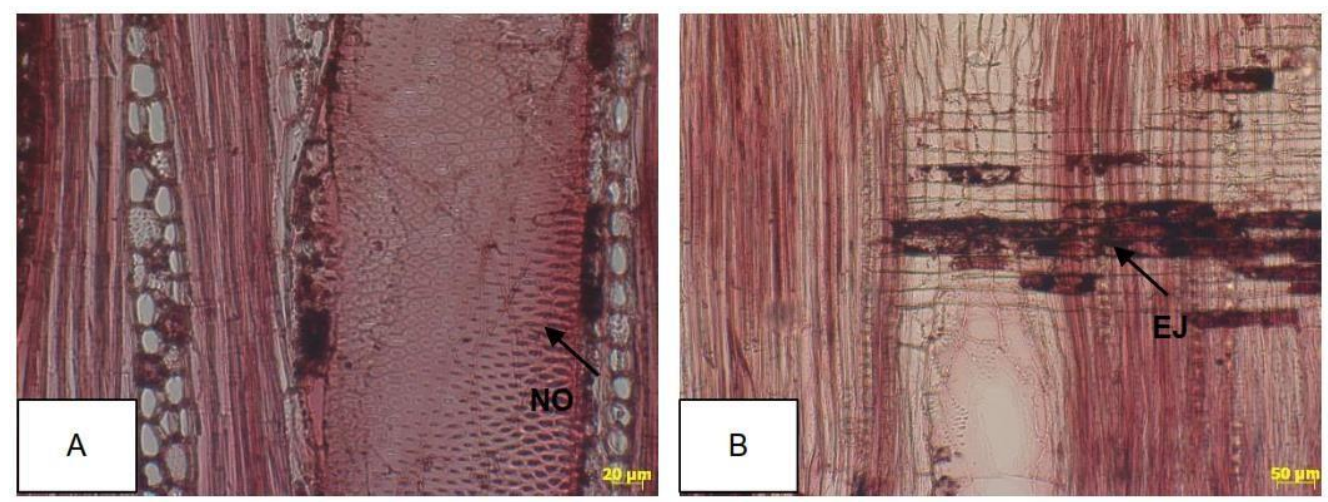

Gambar 7 Noktah (NO) berselang-seling di dinding bersama (A, 200x); dan endapan (EJ) di dalam jari-jari (B, 100x).

Tabel 1 Panjang serat, nilai turunan dimensi serat, dan penentuan kelas mutu serat

\begin{tabular}{|c|c|c|c|c|c|c|}
\hline \multirow{3}{*}{ Parameter } & \multicolumn{6}{|c|}{ Jenis kayu } \\
\hline & \multicolumn{2}{|l|}{ Nyatoh } & \multicolumn{2}{|c|}{ Pisang putih } & \multicolumn{2}{|l|}{ Sepetir } \\
\hline & Nilai & Skor & Nilai & Skor & Nilai & Skor \\
\hline $\mathrm{PS}(\mu \mathrm{m})$ & $1903,69 \pm 138,56$ & 50 & $1708,39 \pm 57,39$ & 50 & $1337,25 \pm 184,48$ & 50 \\
\hline $\mathrm{RR}$ & $0,30 \pm 0,03$ & 50 & $0,54 \pm 0,04$ & 25 & $0,62 \pm 0,03$ & 25 \\
\hline FP (\%) & $55,85 \pm 6,52$ & 50 & $53,65 \pm 1,47$ & 50 & $75,00 \pm 11,44$ & 50 \\
\hline $\operatorname{MR}(\%)$ & $40,13 \pm 2,96$ & 50 & $55,99 \pm 2,68$ & 50 & $60,69 \pm 1,17$ & 25 \\
\hline FR & $0,77 \pm 0,02$ & 50 & $0,66 \pm 0,02$ & 50 & $0,62 \pm 0,01$ & 50 \\
\hline \multirow[t]{3}{*}{$\mathrm{CR}$} & $0,11 \pm 0,01$ & 50 & $0,17 \pm 0,01$ & 25 & $0,19 \pm 0,01$ & 25 \\
\hline & Total skor & 300 & & 250 & & 225 \\
\hline & Kelas mutu & III & & III & & III \\
\hline
\end{tabular}


semakin tinggi mutu pulp dan kertas yang akan dihasilkan. Nilai MR serat kayu Acacia spp. berkisar 45-55\% (Yahya et al. 2010). Di antara ketiga jenis kayu, hanya nyatoh yang memiliki nilai MR yang lebih rendah dari akasia. Dengan demikian, dapat dipastikan lembaran pulp dan kertas yang terbuat dari serat kayu nyatoh akan lebih kuat dibandingkan dengan yang terbuat dari serat kayu akasia.

Rata-rata nilai FR juga bervariasi menurut jenis kayu. Serat kayu nyatoh memiliki nilai FR yang tertinggi $(0,77)$, serat kayu pisang putih memiliki nilai FR sedang, yaitu 0,66 , sedangkan serat kayu sepetir paling rendah $(0,62)$. Rata-rata FR serat kayu nyatoh bahkan lebih tinggi daripada FR serat kayu Acacia spp. dan Eucalyptus spp., masing-masingnya 0,67 dan 0,74 (Ona et al. 2001; Yahya et al. 2010). Menurut Ona et al. (2001); Ashori \& Nourbakhsh (2009), semakin tinggi FR akan semakin tinggi pula kerapatan, burst factor, breaking length, dan ketahanan lipat lembaran pulp dan kertas yang dihasilkan. Hasil pengukuran juga memperlihatkan serat kayu nyatoh memiliki rata-rata $\mathrm{CR}$ yang paling rendah, yakni 0,11 , sedangkan serat kayu sepetir tertinggi $(0,19)$. Rata-rata CR serat kayu pisang putih adalah 0,17 . Rata-rata $C R$ serat kayu nyatoh juga lebih rendah dibandingkan CR kayu Acacia spp., yakni 0,13-0,17 (Yahya et al. 2010). Semakin rendah CR akan semakin tinggi pula kekuatan tarik dan burst factor lembaran pulp dan kertas yang akan dihasilkan.

Meskipun memiliki keragaman dalam hal panjang serat dan nilai turunan dimensinya, hasil skoring (Tabel 1) memperlihatkan serat ketiga jenis kayu masuk dalam Kelas Mutu III. Menurut Soijonkari-Pahlaka (2001); Emerhi (2012); Sharma et al. (2013); Fatriasari et al. (2015); Amoo et al. (2016), serat dengan Kelas Mutu III cenderung menghasilkan lembaran kertas yang tebal dan kasar dengan kekuatan robek yang tinggi, namun kekuatan tariknya rendah. Di antara ketiga jenis kayu, kayu nyatoh lebih berpotensi digunakan sebagai bahan baku pembuatan pulp dan kertas karena memiliki nilai skor yang lebih tinggi.

\section{Sifat Fisis Ketiga Jenis Kayu}

Rata-rata hasil pengujian KA, kerapatan, dan BJ kayu kondisi kering udara, serta susut masing-masing dimensi dan T/R-rasio dari basah ke kondisi kering udara untuk masing-masing jenis disajikan dalam
Tabel 2. Berdasarkan analisis $t$-student pada selang kepercayaan $95 \%$ diketahui sifat fisis kayu bervariasi dan bergantung pada jenis, kecuali susut radial dan T/R-rasionya.

Rata-rata nilai KA dan kerapatan kering udara ketiga jenis kayu berturut-turut adalah $14,63 \%$ dan 0,49 $\mathrm{g} / \mathrm{cm}^{3}$ untuk nyatoh, $16,91 \%$ dan $0,43 \mathrm{~g} / \mathrm{cm}^{3}$ (pisang putih), serta $15,59 \%$ dan $0,37 \mathrm{~g} / \mathrm{cm}^{3}$ (sepetir). Nilai-nilai $\mathrm{KA}$ tersebut termasuk selang nilai KA kondisi kering udara untuk wilayah Bogor dan sekitarnya sebagaimana dinyatakan oleh Seng (1990). Lebih tingginya KA kayu pisang putih dibandingkan KA kayu nyatoh dan sepetir ada kaitannya dengan karakteristik anatomi yang dimilikinya, terutama porsi jari-jari multiseriate yang lebih tinggi. Jari-jari yang demikian akan lebih banyak mengikat air sebagaimana dilaporkan oleh Ahmed \& Chun (2009). Hasil pengukuran memperlihatkan BJ kayu sepetir kondisi kering udara adalah yang paling rendah $(0,32)$, sedangkan BJ kayu nyatoh paling tinggi $(0,42)$. Ratarata BJ kayu pisang putih adalah 0,37 . Dengan nilai BJ yang demikian maka kayu sepetir dan pisang putih masuk ke dalam Kelas Kuat IV, sedangkan kayu nyatoh Kelas Kuat III (PKKI 1961).

Tiga jenis kayu perdagangan yang masuk Kelas Kuat IV adalah sengon (Falcataria moluccana), jelutung (Dyera costulata), dan pulai (Alstonia scholaris); sedangkan yang masuk Kelas Kuat III adalah jabon (Anthocephallus cadamba), gmelina (Gmelina arborea), dan terentang (Campnosperma sp.) (Martawijaya et al. 1989 dan 2005; Abdurohim et al. 2004). Kenyataan ini mengindikasikan kayu sepetir dan pisang putih sebetulnya dapat digunakan sebagai pengganti kayu sengon, jelutung, dan pulai; sedangkan kayu nyatoh dapat menggantikan fungsi kayu jabon, gmelina, dan terentang. Kisaran nilai BJ kayu untuk bahan baku pembuatan mebel adalah $0,40-0,60$ (BSN 1989). Hal tersebut mengindikasikan kayu nyatoh juga berpotensi dijadikan bahan baku, sedangkan kayu sepetir dan pisang putih tidak. Dengan nilai BJ kayu yang $<0,50$, maka ketiga jenis kayu dapat ditingkatkan mutunya. Untuk keperluan tersebut, perlu ditemukan teknik peningkatan mutu terbaik untuk masing-masing jenis.

Tabel 2 juga memperlihatkan adanya keragaman besar susut yang terjadi baik antardimensi maupun antarjenis. Secara keseluruhan, susut longitudinal

Tabel 2 Rata-rata nilai sifat fisis pada tiga jenis kayu

\begin{tabular}{|c|c|c|c|c|}
\hline Parameter & Nyatoh & $\begin{array}{l}\text { Jenis kayu } \\
\text { Pisang putih }\end{array}$ & Sepetir & $\begin{array}{l}\text { Signifikansi } \\
\text { antar-jenis }\end{array}$ \\
\hline Kadar air (\%) & $14,63 \pm 0,75$ & $16,91 \pm 0,76$ & $15,59 \pm 1,08$ & $\star *$ \\
\hline Kerapatan $\left(\mathrm{g} / \mathrm{cm}^{3}\right)$ & $0,49 \pm 0,06$ & $0,43 \pm 0,06$ & $0,37 \pm 0,04$ & ** \\
\hline BJ & $0,42 \pm 0,05$ & $0,37 \pm 0,05$ & $0,32 \pm 0,03$ & $* *$ \\
\hline Susut longitudinal (\%) & $0,46 \pm 0,12$ & $0,63 \pm 0,16$ & $0,74 \pm 0,18$ & ** \\
\hline Susut radial (\%) & $2,88 \pm 0,51$ & $2,16 \pm 0,39$ & $2,65 \pm 0,35$ & ns \\
\hline Susut tangensial (\%) & $3,94 \pm 0,48$ & $4,88 \pm 0,57$ & $3,68 \pm 0,35$ & ** \\
\hline T/R-rasio & $1,41 \pm 0,33$ & $2,34 \pm 0,56$ & $1,40 \pm 0,12$ & ns \\
\hline
\end{tabular}

Keterangan: $\mathrm{KA}$ = Kerapatan dan BJ kayunya dalam kondisi kering udara, susut pada ketiga dimensi dan T/R-rasio diukur dari kondisi basah ke kondisi kering udara, $\mathrm{ns}=$ Tidak signifikan, dan ${ }^{*}$ = Signifikan pada selang kepercayaan $99 \%$. 
pada ketiga jenis kayu merupakan susut yang terkecil, sedangkan susut tangensial yang terbesar. Fenomena ini sesuai dengan laporan Clair et al. (2008) yang menyatakan bahwa susut terkecil terdapat pada arah longitudinal, kemudian diikuti susut arah radial, dan yang terbesar pada arah tangensial. Untuk tujuan praktis, susut longitudinal bahkan dapat diabaikan.

Rata-rata susut longitudinal, radial, dan tangensial pada kayu nyatoh masing-masingnya adalah 0,46, 2,88 , dan $3,94 \%$. Pada kayu sepetir secara berurutan adalah 0,$74 ; 2,65$; dan $3,68 \%$; sedangkan pada kayu pisang putih adalah 0,$63 ; 2,16$; dan 4,88\%. Meskipun kayu-kayu berBJ tinggi pada umumnya akan menyusut lebih banyak (Peck 1957), kenyataan yang ada bisa saja berbeda akibat perbedaan sudut mikrofibril dan keberadaan noktah di dinding sel. Fenomena ini terjadi pada kayu nyatoh di mana besar susut volumenya cenderung lebih rendah dibandingkan susut volume kayu pisang putih yang BJnya lebih rendah. Itulah sebabnya karakteristik penyusutan dan besar susut masing-masing dimensi pada setiap jenis kayu sangat perlu untuk dipahami dalam rangka mengantisipasi perubahan bentuk dan ukuran (deformasi) yang mungkin terjadi.

Dari nilai T/R-rasio (Tabel 2) dapat dipastikan kayu nyatoh dan sepetir tergolong stabil, sedangkan kayu pisang putih tidak. Rata-rata T/R-rasio kayu sepetir dan nyatoh dari kondisi basah ke kering udara hampir sama (1,40 dan 1,41), sedangkan pada kayu pisang putih adalah 2,34. Nilai T/R-rasio juga mengindikasikan mudah-tidaknya kayu berubah bentuk dan ukuran selama proses pengeringan (Bossu et al. 2016). Menurut Shukla \& Kamdem (2010), stabilitas dimensi kayu dipengaruhi oleh jenis kayu, struktur anatomi, komposisi kandungan kimia, terutama kadar dan distribusi lignin, tebal dinding, proporsi kayu awal dan akhir, sudut mikrofibril, dan kadar air awal kayu.

\section{KESIMPULAN}

Dari segi anatomi, ciri khas kayu nyatoh adalah pori-pori dominan bergabung radial dan berisi tilosis; jari-jari satu ukuran, halus dan rapat; parenkim aksial tipe garis tangensial pendek dengan jarak yang tidak teratur; dengan rata-rata panjang dan tebal dinding serat sebesar 1903,69 dan 3,61 $\mu \mathrm{m}$. Ciri anatomi kayu pisang putih adalah pori-pori dominan soliter, jari-jari dua ukuran, parenkim aksial tipe pita tangensial panjang dalam jarak yang tidak teratur, dengan ratarata panjang dan tebal dinding serat sebesar 1708 dan 4,51 $\mu \mathrm{m}$. Ciri khas kayu sepetir adalah pori-porinya soliter dalam arah radial dan tangensial, jari-jari dua ukuran tapi kurang jelas, parenkim aksial tipe keliling pembuluh hingga aliform, memiliki saluran antarsel dalam bentuk deretan tangensial panjang, dengan rata-rata panjang serat dan tebal dinding serat adalah 1337 dan 3,39 $\mu \mathrm{m}$.

Rata-rata BJ kayu dan T/R-rasio untuk masingmasing jenis adalah 0,42 dan 1,41 (nyatoh), 0.37 dan
2,34 (pisang putih), serta 0,32 dan 1,40 (sepetir). Kayu nyatoh dan sepetir tergolong stabil, sedangkan kayu pisang putih tidak. Kayu nyatoh masuk ke dalam Kelas Kuat III, sedangkan pisang putih dan kayu sepetir Kelas Kuat IV. Dibandingkan pisang putih dan sepetir, kayu nyatoh lebih berpotensi sebagai bahan baku pembuatan pulp dan kertas serta mebel.

\section{UCAPAN TERIMA KASIH}

Penulis mengucapkan terima kasih kepada Direktorat Jenderal Pendidikan Tinggi (DIKTI) atas bantuan biaya penelitian yang diberikan melalui skema PMDSU Batch II. Selain itu, ucapan terima kasih juga ditujukan kepada Dr. Krisdianto dan Dr. Ratih Damayanti, peneliti di Laboratorium Anatomi Tumbuhan, Pusat Penelitian dan Pengembangan Hasil Hutan, Gunung Batu, Bogor, yang telah membantu dalam memperlancar proses penelitian ini.

\section{DAFTAR PUSTAKA}

Abdurohim S, Mandang YI, Sutisna U. 2004. Atlas Kayu Indonesia Jilid III. Bogor (ID): Badan Penelitian dan Pengembangan Kehutanan.

Ahmed SA, Chun SK. 2009. Observation of liquid permeability related to anatomical characteristics in Samanea saman. Turkish Journal of Agriculture and Forestry. 33: 155-163.

Amoo K, Onilude M A, Omoniyi T E. 2016. Fibre characteristics of paper and paper egg tray used in Southwest Nigeria. Internati International Journal of Engine Research and Reviews. 4 (4): 53-60.

Ashori A, Nourbakhsh A. 2009. Studies on Iranian cultivated paulownia-a potential source of fibrous raw material for paper industry. Europia Journal of Wood and Wood Products. 67: 323-327. https:// doi.org/10.1007/s00107-009-0326-0

Augustina S. 2019. Sifat dasar tiga jenis kayu lesserused species dan peningkatan mutunya melalui teknik densifikasi. [Tesis]. Bogor (ID): IPB University.

Boer E, Ella AB. 2000. Plant Resources of South-East Asia 5(18). Plant Producing Exudates. Leiden (NL): Backhuys Publishers.

Bossu J, Beauchene J, Estevez Y, Duplals C, Clair B. 2016. New insight on wood dimensional stability influenced by secondary metabolites: The case of a fast-growing tropical species Bagassa guianensis Aubl. Plos One. 11(3): 1-17. https://doi.org/ 10.1371/journal.pone.0150777

Bowyer JL, Shmulsky R, Haygreen JG. 2003. Hasil Hutan dan IImu Kayu Suatu Pengantar, Terjemahan 
[Third Edition]. Yogyakarta (ID): Gadjah Mada University Press.

[BSI] British Standard. 1957. Methods of Testing Small Clear Specimens of Timber. BS 373:1957. London (UK): British Standard Institute.

[BSN] Badan Standarisasi Nasional. 1989. Kayu untuk mebel, syarat sifat fisik dan mekanik. SNI 01-06081989. Jakarta (ID): Badan Standarisasi Nasional.

Cahyono TD, Wahyudi I, Priadi T, Febrianto F, Bahtiar ET, Novriyanti E. 2016. Analysis on Wood Quality, Geometry Factor, and Their Effects on Lathe Check of Samama (Anthocephalus macrophyllus) Veneer. Journal of the Korean Wood Science and Technology. 44(2): 828-841. https://doi.org/ 10.5658/WOOD.2016.44.6.828

Chowdhury MdQ, Ishiguri $F$, Hiraiwa $T$, Matsumoto $K$, Takashima Y, Lizuka K, Yokota S, Yoshizawa N. 2012. Variation in anatomical properties and correlations with wood density and compressive strength in Casuarina equisetifolia growing in Bangladesh. Australian Forestry. 75(2): 95-99. https://doi.org/10.1080/00049158.2012.10676390

Clair B, Gril J, Di Renzo F, Yamamoto H, Quignard F. 2008. Characterization of a gel in the cell wall to elucidate the paradoxical shringkage of tension wood. Biomacromolecules. 9 (2): 494-498. https://doi.org/10.1021/bm700987q

Damayanti R, Mandang YI, Waluyo TK. 2007. Struktur anatomi dan kualitas serat batang kemenyan (Styrax spp.) dari Sumatera Utara. Jurnal Penelitian Hasil Hutan 25(3): 273-290. https:// doi.org/10.20886/jphh.2007.25.3.273-290

Damayanti R, Rulliaty S. 2010 Anatomical properties and fiber quality of five potential commercial wood species from Cianjur, West Java. Journal of Forestry Research. 7(1): 53-69. https://d oi.org/10.20886/ijfr.2010.7.1.53-69

Din H, Metali F, Sukri RS. 2015. Tree diversity and community composition of tutong white sands, Brunei Darussalam: A rare tropical heat forest ecosystem. Internasional Journal of Ecology. 2015(10). https://doi.org/10.1155/2015/807876

Emerhi E A. 2012. Variations in anatomical properties of Rhizophora racemosa (leechm) and Rhizophora harrisonii (g. mey) in a Nigerian mangrove forest ecosystem. International Journal of Forest, Soil and Erosion. 2(2): 89-96.

[FAO] Food and Agriculture Organization of the United Nations. 1984. Lesser-known tropical wood species. Rome (IT): FAO Forestry Paper 36.

Fatriasari W, Supriyanto, Iswanto AH. 2015. The kraft pulp and paper properties of sweet sorghum bagasse (Sorghum bicolor L Moench). Journal of Engineering and Technological Sciences. 47(2):
149-159. https://doi.org/10.5614/j.eng.technol. sci.2015.47.2.4

Florensius M, Herawatiningsih R, Dewantara I. 2018. Ekologi dan potensi pohon nyatoh (Palaquium spp.) di hutan sekunder areal IUPHHK-HTI PT. Bhatara Alam Lestari Kabupaten Mempawah. Jurnal Hutan Lestari. 6(2): 311-317.

[FPL] Forest Products Laboratory. 2010. Wood Handbook-Wood as an engineering material. General Technical Report FPL-GTR-190. Madison (US): Departement of Agriculture, Forest Service, FPL.

[FPRDI-ITTO] Forest Products Research and Development Institute-International Tropical Timber Organization. 1997. Manual on The Properties and Uses of Lesser-Used Species of Philippine Timbers. Laguna (PHL): FPRDI-ITTO Project.

Green DW, Begel M, Nelson W. 2006. Janka Hardness Using Nonstandard Specimens. Madison (US): FPL. https://doi.org/10.2737/FPL-RN-303

Hamdan S, Jusoh I, Rahman MdR, de Juan M. 2016. Acoustic properties of Syzygium sp., Dialium sp., Gymnostoma sp., and Sindora sp. wood. BioResources. 11(3): 5941-5948. https:// doi.org/10.15376/biores.11.3.5941-5948

Handayani T. 2018. Diversity, potential and conservation of Annonaceae in Bogor Botanic Gardens, Indonesia. Biodiversitas. 19(2): 591-603. https://doi.org/10.13057/biodiv/d190230

IAWA. 2008. Identifikasi Kayu: Ciri Mikroskopis Untuk Identifikasi Kayu Daun Lebar. Bogor (ID): Pustekolah.

Istikowati $\mathrm{WT}$, Aiso $\mathrm{H}$, Sunardi, Sutiya $\mathrm{B}$, Ishiguri $\mathrm{F}$, Ohshima J, Lizuka K, Yokoya S. 2016. Wood, chemical, and pulp properties of wood from lessutilized fast-growing tree species found in naturally regenerated secondary forest in South Kalimantan, Indonesia. Journal of Wood Chemistry and Technology. 36(4): 250-258. https:// doi.org/10.1080/02773813.2015.1124121

[ITTO] International Tropical Timber Organization. 2019. Tropical timber-lesser used species [internet]. [diacu $2020 \quad 16$ Juli]. Tersedia dari: http://www.tropicaltimber.info/specie/ mempisangmezzettia-parviflora.

[ITTO] International Tropical Timber Organization. 2019. Tropical timber-lesser used species [internet]. [diacu $2020 \quad 16$ Juli]. Tersedia dari: http://www.tropicaltimber.info/specie/ sepetirsindora-coriacea.

Koek-Noorman J, Westra LYT. 2012.

Macrophotographic wood atlas of Annonaceae. Botanical Journal of the Linnean Society. 169: 135-189. https://doi.org/10.1111/j.1095- 
Mandang YI, Suhaendra H. 2003. Sifat-sifat kayu nyatoh (Palaquium obtusifolium Burck.) sehubungan dengan kemungkinan penggunaannya sebagai bahan bilah pensil. Buletin Penelitian Hasil Hutan. 21(1): 1-14.

Mardikanto TR, Karlinasari L, Bahtiar ET. 2011. Sifat Mekanis Kayu. Bogor (ID): IPB Press.

Martawijaya A, Kartasujana I, Mandang YI, Prawira SA, Kadir K. 1989. Atlas Kayu Indonesia Jilid II. Bogor (ID): Badan Penelitian dan Pengembangan Kehutanan.

Martawijaya A, Kartasujana I, Kadir K, Prawira SA. 2005. Atlas Kayu Indonesia Jilid I. Bogor (ID): Badan Penelitian dan Pengembangan Kehutanan.

Ogata K, Fujii T, Abe H, Haas P. 2008. Identification of the Timbers of Southeast Asia and the Western Pacific. Tsukuba (JP): Kaiseisha Press. https:// doi.org/10.1515/HF.2008.132

Ona T, Sonoda T, Ito K, Shibata M, Tamai Y, Kojima Y, Ohshima J, Yokota S, Yoshizawa N. 2001. Investigation of relationships between cell and pulp properties in Eucalyptus by examination of withintree property variations. Wood Science and Technology. 35: 229-243. https://doi.org/ $10.1007 / \mathrm{s} 002260100090$

Peck EC. 1957. How wood shrinks and swells. Forest Products Journal. 7(7): 235-244.

Peng $\mathrm{H}$, Jiang J, Zhan T, Lu J. 2016. Influence of density and equilibrium moisture content on the hardness anisotropy of wood. Forest Products Journal. 66(7-8): 443-452. https://doi.org/ 10.13073/FPJ-D-15-00072

[PKKI-NI5]. 1961. Peraturan Konstruksi Kayu Indonesia. Jakarta (ID): Yayasan Dana Normalisasi Indonesia.

Porombi S, Umar H, Taha I. 2017. Pertumbuhan cabutan anakan alam nyatoh (Palaquium sp.) setelah disimpan pada wadah yang berbeda. Warta Rimba. 5(1): 49-54.

Rulliaty S. 1994. Wood quality indicators as estimator of juvenile wood in Mahagony (Swietenia macropylla King) from forest plantation in Sukabumi, West Java, Indonesia. [Tesis]. Los Banos (PH): UPLB.

Seng OD. 1990. Berat Jenis dari Jenis-jenis Kayu Indonesia dan Pengertian Beratnya Kayu untuk Keperluan Praktek. Pengumuman No.13. Bogor (ID): Lembaga Penelitian Hasil Hutan.

Sharma M, Sharma CL, Kumar YB. 2013. Evaluation of fiber characteristics in some weeds of Arunachal Pradesh, India for pulp and paper making. Research Journal of Agricultural Science. 1(3):15-21.

Shukla SR, Kamdem DP. 2010. Dimensional stability of nine tropical hardwood from Cameroon. Journal of Tropical Forest Science. 22 (4): 389-396.

Soijonkari-Pahlaka K. 2001. Non-wood plants as raw material for pulp and paper. [Disertation]. Jokioinen (FIN): University of Helsinki. https:// doi.org/10.23986/afsci.5707

Sosef MSM, Hong LT, Prawirohatmodjo S, 1998. Plant Resources of South-East Asia 5(3). Timber trees: Lesser-known timbers. Leiden (NL): Backhuys Publishers.

Wahyudi I. 2013. Hubungan struktur anatomi kayu dengan sifat kayu, kegunaan dan pengolahannya. Diskusi Litbang Anatomi Kayu Indonesia. Bogor 3-4 Juni 2013. Bogor (ID): Asosiasi Anatomi Kayu Indonesia. hlm. 1-12.

Wasis B, Baskara H. 2013. Pertumbuhan semai nyatoh pada media tailing PT. Antam unit bisnis Pongkor pada penambangan arang tempurung kelapa dan pupuk kompos bokashi. Jurnal Silvikultur Tropika. 4(1): 1-5.

Winandy JE. 1994. Wood Properties. Di dalam Arntzen CJ, Editor. Encyclopedia of Agricultural Science. Orlando (US): Academic Press. hlm. 549-561.

Yahya R, Sugiyama J, Silsia D, Gril J. 2010. Some anatomical features of an Acacia Hybrid, $A$. mangium and $A$. auriculiformis grown in Indonesia with regard to pulp yield and paper strength. Journal of Tropical Forest Science. 22(3): 343-351. 